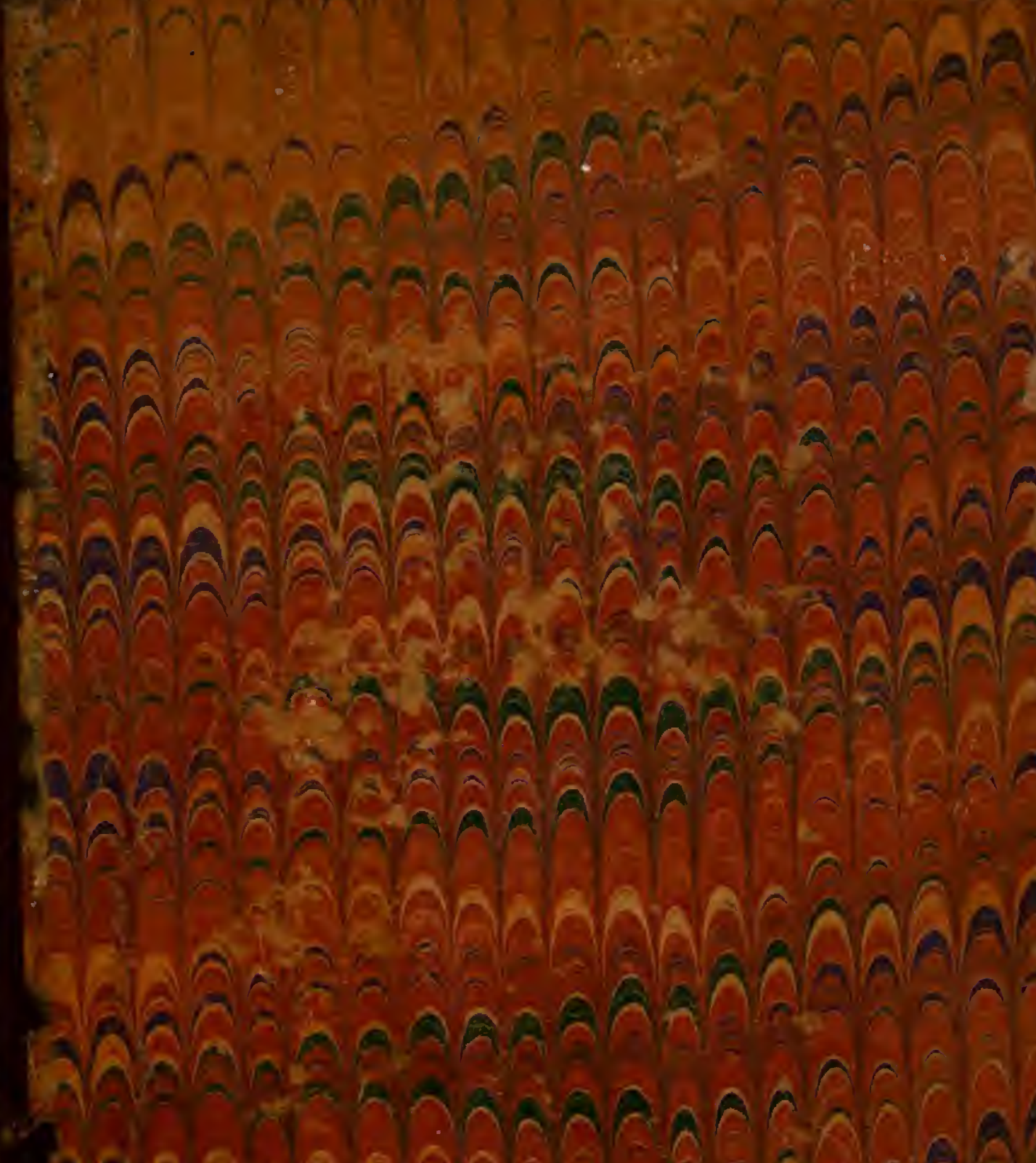

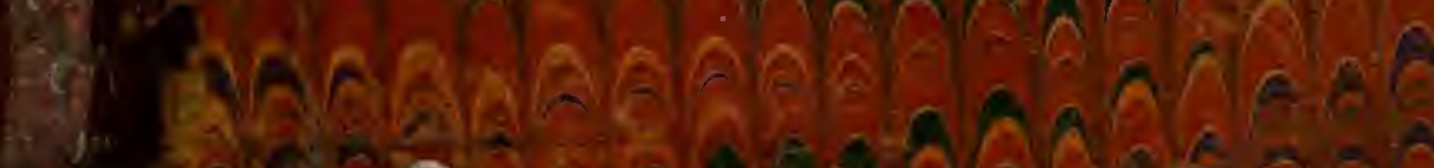
V. RBS 638.20959513 WRA 


\section{RAFFLES LIBRARY, SINGAPORE.}

\section{RULES.}

1. Atl persons shall be admitted to the l.ibrary and Reading from on riving their name, and address to the librarian, or l.ibrary Clerk, but they shall not be entiled ta borrow bowk unless they are.subscribers.

2. The Libraty and Reading Room slanl be open dalty from 9. 30 A.M. to 6. P.M. except ou Sundays when they shall be closed.

3. A single subseription to the I.ending I.ilvary shall be for an class subscribers \$12 for a yeat or $\$ 6$ for a half-vear, for and Class subscribers so for a jear or so for

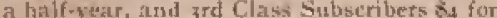
a year or Sa for a halfuear, payable at the l.ibrary to the I. ibrariar or Library Cierk

No Receipt should be accepted nuless it be or a printed form with consecutive numbering:

Al] Stubscriptions stall be pald In advance, and two bouk shall be yivets ont to any merson unless fild until his subseription has been paid.

4. Yearly subscriptions shall be due on the 1st, January, and half-yearly $94 \mathrm{~b}$. seriptions on the ist lanuary and ist July, asd if not paid within ane month after becoming due the defatilter shall cease to be a Subscriber.

5. First-Class Sulnscribers shalt be entitled for atch subscription to hurros" four complete works, but not more thiss seven vulurmes at ane rime, and Class sisbscribers iwo complete works, but not more than four walumes at one time, and 3rd Class Sub. seibers one complete work, but not more than two volutnes at alle rime. Silbscribers in berrowing books Inust either appiy persontially, or send a signed note before any book cat be delivered. All applications for hryoks sinal! be dealt whith in orders of prority.

6. Subseribers are on no account to pass

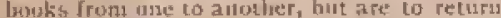
them th the Lihritry. No books shatl be fert: by a Sulastriber to a Non-subseriber.
7. The time allowed for the perwsal of cach book shiall be :-

for buoks that have been in the 1,ibrary for a year, Orie Mantli, fot other bouks, Seven [lays, and for Mayazines and Jiews. papers Three Days. Maguzines and Newspapers shall not be issued to subscribers until after the recuipt of the stccedfrg number.

8. A finc of ro centon a lay shall be bevled for each day a bork is kcpt bejond tlas perind allowed by Rule 3 , and after notice requiring its return has been grisen.

a. Any persian who ghall lose of seriously injure athy bomk or publicationa shadl pay the full cost of replacing it.

10. Nin buste in the reference Library shall be lent unless special permiasion be obtained irom the Commitce through the libratiku.

Ir. If any line shall be unpata for one month aftes rabtice reouirisg prosment, the persoli frotiz whom the same is due shall cease to be entitled to any of the privileges of the l.tbrary tintil such tine is patid.

12. Subscrikurs are strictly forbidden to take nway from the I.ibrary any Rooks, lamphlel. Periedical or Vewspaper, witls. wat first having it registered by tist Library Cleek.

13. Petsons desirous of becoming Subscribers must state namt, nccupation, ind plite of residence, ind sitbseribers mut fusify wo the l.ibrarian any change of resldence.

14. The subseription of a member only entirles himself, and the inembers of his uw. fa fally Tesidervt in the same hause with him ta the uke of Library bonks.

15. Persons staying in Hotels desirong of becoming subseribers shall futmish a guarantex to the satisfaction of the l.ibrariau, unless they are vell-known Singapore residents.

\section{OUT-STATIONS.}

The Committee may extend the privileges of the Library to OutStations on terms specially to be arranged. 




perâ Mutuscum Motes. Mo. 1.

ON THE EXPERIMENTAL CULTURE OF SILKWORMS IX PERAK, EIC. 


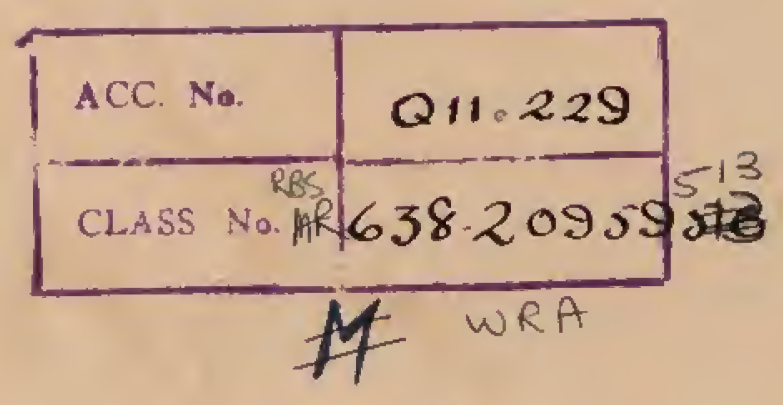




\title{
EXPERIMENTAL CULTURE
}

\author{
OF \\ SILKWORMS IN PERAK, \\ TOGETHEK WITH A PAPER ON THE MALAYAN FISH POISON \\ "AKER TUEA," AND A NOTE ON A LIGHTNING \\ DISCHARGE IN TAIPING. ALSO A NOTE \\ ON THE DLACK LIMESTONE AT \\ KAMUNTNG. \\ แx \\ I. WRAl, JUN.. \\ M.1.E.E., L.3.s., colk. MLM. H.s.. ETt.
}

Eaiping :

I'ERAK GOVERNMLNT PRINTING OFI'ICE.

1893. 


\section{NOTICE.}

From time to time, as moterial is avaliable, it is proposed to publish, in pamphlet form, paris of a serial under the titite of Foral Muscum Noter. The pilpers in it will deal with and illustrite Musenn and genemal seientifio subjects ronnected witl: the State of Perali, its listory, trade, industries, mines and products.

Communientions and puters on the sulpects indicated above are invited. 


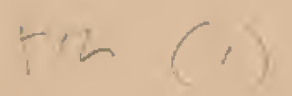

\section{ON THE EXPERIMENTAL CULTURE OF SILKWORMS IN PERAK.}

Iñ November, 1889, a small Chinese company, after lavin utrares and planted up a few acres of land with mulberrius at A yer Kuning, in Tamt, intrednes from never Canton, in Chini, sime silk worn ergs. These eggs latched, and successive broods of the worms were raised and seened to thrive in a perfectly satisfactory luanner.

Mr. F. Light then plauted up some laud at Ayer Kuning with the same mulberries, and begat breding the worms from ugg's given him ly the original Chinese company.

\section{CHINESE METHOD OF CULTURE.}

The oggs are laid on sheets of common rellow Chinese paper, known in the shops as kertas api. When the time arrives for the agys to hateh, the sheets of pajer are laid on bamboo trays aul lightly sprinkled with finely eut mulberry leaves, and the worms as they emerge from the egys crawl on to the cut leaf and are removed with it to fresh trays. These trays are roumd, and are mite of split plaited bambio; they are from two to three and it half feet in dianeter, ank lave i rim of about one and a lualf inches high. 'The worms are liept on these trays, at first on it few; as they grow and roquire more roon, the number of trays is increased. The trays are put ou rough round wood raclis, about nine inches apart. Cut leaf is given for the first five or six lays and then the worms, having grom large enough, are fed on uncut leaf. The trays are kept clean, the refuse leaves, deal and sickly worus, ote., heing removed daily. The houses, which are of the ordinary bigh-pitehed attap roofed Chinese pattern, are kept as much slut up as possible, to exclucte the wind and sull. The west witgd is thought to eause sickness amongst the worms. Lights are lept hurming at night, and the houses are used as dwellings by the cultivators. Snoking, by the lyye, is not allowed as it is thought to be prejudicial to the welfire of 
the worms. When they are full grown, and as they turn yellow, they are picked out of the trays and put on to the coconning frames to spin. These are Iamboo franes with thin strips of curted bimhoo fastened to them on each side, and it is in the loops so formed that the worms spin. The frimes are about two feet by three foet, and are stood up in pairs in the louses when roguired for nst. The spinning completed, the coeoons arc pieked out of the frames by men armed witl small steel forceps. I'lie earliest of the spinners are reserved for breeding and the remainder are stifted. The cocoons kept for breeding are put in a single layer on the bambog rearing trays. When the motlis emerge they are allowed to pair, aud in the evening the pairs are separated, the females being placed on a sheet of common Chinese paper on which a wooden frame is ptaced a little smaller than the size of a sleet of paper. These frames are ahout one mel half incles high. A hoaril is laid on top of the first frame, then a sheet of papur, then anotler frame, which, having been fillud with female moths, is courtred with another board, alnd so on. As soou as the moths have haid they are thromn away, and the sleets of paper, densely covered with eggs, are diynd inter lot water, the water being lieated so that the band ean te horne in it. The sheets are then dried, the date of laying marked on each sheet, and they are rolled up and put away until tluy are ready for latehing. The lipping in hot wates is a matter requiring great care, as if the water is overheafed it kills the eggs. It is said to make the exgs latel more ivenly and is thought to be of grent imponance by the Chinese.*

\section{TREATMENT OF THE SILK.}

The cocoons not required for breeding are put into wooden drawers with gerforated hottons, armuged in it large clust, benoth which are put earthenware chating-disles, in which bhar-

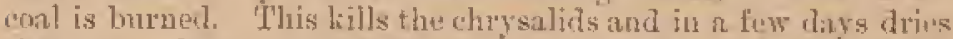

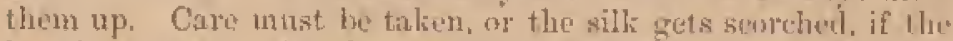
letat is toogreat. Anotler method of stifling used ly the Chinese is to take the cocoming trames full of cotoons and heap them "1p, and then cover them all closely over with cloths. 'T'le chafinlishes with burnigg thareoal are then put underneatl the pile nud the stifling ensiles.

* I hase forend that if the eggs laid lyy a pebrinous moth atro waberl,

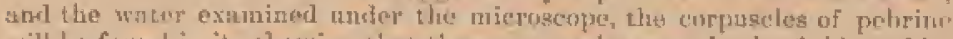

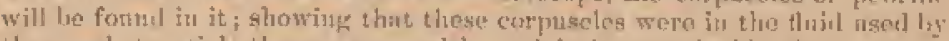
the moth to stick the egges on with, nud it is conceivalule that a noti. whicl had become rlisensed tate in lift, and after the reges two formed,

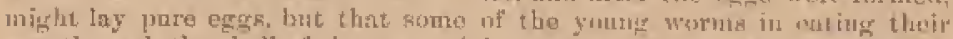

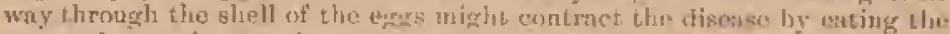

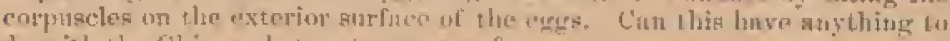
do witl the Chiboso het water process? 
When killed and dried the cononns are sorted into yellows and whites, or as the Chinese express it, gold and silrer, all damared eocoons heing put by themserves together with the piereed eocons which have been used for breeding purposes.

The reooons are sent to Hongkong and from there to Hanghat, where they ure sold. A man heing sent with eash consignment of silk, the transport expenses are very considerable. In

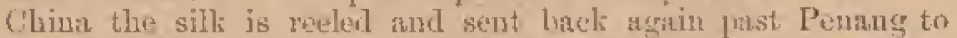
Europe. The price of well reeled silk in Chin is 85 per lati, while badly reeled silk only fetelos \$3.

An attennt was mare to introduce some female reeders from China, but withont suecess, owing to the diflienity of getting then out of the comntry. There is one woman in Jarut who can reel, but she left China whed very youmg and is therefore not an exprert hand. 'The apparatis tised in reeting is very sinple. and only costs from $\$ 3$ to $\$ 5$.

In some olsserwations that. I made on the reild of silk I fomul that the average weight of the cocoons when fresh was 10.75 grains. 651 going to the pound. I estimated that 5.838 anomons wonld yeild one protud of reeled silk, besides the floss silli.

Mr. F. Tight sent simples of the Ayer Kuning cocoons to Messis. C. S. Tennent \& Co., of Penaug. who otstaned the following intersting report on them from their correspondents at Marseilles. "Wu thanl you for your acom samples marked Yand D, which we have submitted to our broker. The conoms you send ase unperced itod are similat to what are reseived from Bengal. and viry goom simples of their lind. Our broker hass never sean anything of exactly the sime kind. Fon will notice that each rociwat lins an outer wrelope of tough silk, and this should he remored in Penang and shipped is silk waste: it is worth from 1 to 1.50 frunes per kils, landed terms (this is, abunt $17 !$ to 26 cents per kati). Te grive an exact valuation it is however. mecessary to kbow what the silk emtents of your tocoous aret.

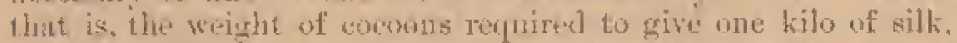
and hefore this is linown it is impossible to say what the cruons would fetch, as spinness thumselves are in complete nucerlanty lefore ntaking a spiuning trial of the cocoons. Bengal and China Inpitured cocoons are fiequenty sold with the graranted that 4. kilos weight of eroms at a certain temprature stall give one kilo weight of silk, and if the 4 kilos wejght of coeoons give, sity. 1. 100 kilos silk, the buyer pays 10 jer ount over contract frice,

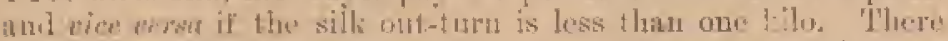
is a silk Trarde Association bere aml at Lyous, hy which the spinuing trials are makle, and the spinners mames are untinown to 
either buyer or seller. Of course these are very complicated and flelicate trials, and only people with a large experience in the article sell on these guntantec terms, though eocoons produced by silkworms from the same place, fed in the same manner and under the sane elinatic conditions, vary very little in the silk out-turus they yield.

-The best way to ret into the bnsiness is to ask Penang to seud as soon as possilile about 10 kilos ( $16 \frac{1}{2}$ katis) of $\mathrm{T}_{\text {, and }}$ the same quantity of D, renoving the outer envelope, and witla these we will have spinning trials male by the Asscrittion, and will then have a lasis for future brisiuess, and lnow the exact ralue of the cocoons. We will then be able to sell on tale quale ferms, without guarantere.

"Your cocoons are linow as unpierced spinning cocoons (cncons non percis a filer), and probluce the so-called 'satin sillk' (soie saline). They might be worth about 5 to $b$ francs per kilo, but until their silk yield is known, any valuation is very loose and variation liable."

\section{THE VARLETY OF SILKWORM.}

As has been previously stated, the breed was introduced from near Canton. They apjear to be the varicty known as bombys sinchsis, which is a small multivoltine spectes, inforior to some of the Indian breeds. It appens to be not at true multivoltine, as there is always a certain proportion of the egrs which refuse to hatels, and which asstume the appearanee of ammal eggs, and evidently require the cold of a winter before they will ferminate. Sometimes these annual exas form a considerable: percentage of the whole laying. It would appear that in China these worms lay multivoltine euss during the summer, and in the antumn lay esges which do not hatch until the following sprjug. A second inportation of eggs was made from China, and I blifained a few and rared them for three generations, and them they lied out in consegunee of all the ergs bejng of the kind which require exposure to cold before they will hateh. 'I'lose' ergs which only slightly darken to a yellow are the quiek-hateling arges. On the fifth of sixth diy they turis to a pretty pite French wrey. the heads of the worms then appenc as biate dots, and on the serunth day they hateh ont. 'Tlue other eugs, sn the conirary, lecris to durken soon after they are haicl. and on the third or fourth day have become brown or purplish hrown, and may them he kept for montls without further diange. The engs which were hrought from Chinit were all of this shareter. They reached here in November, so were: the antamm layiner.

The life history of this worm will be seen by the following notes, made on some that I reared in 1890 . From the liying of 
the eggs to the hateling took between six and seven days, the eggs being kept in a cool place. The first change of skin took phoe on the seventh day, the second on the tevth, the third on the fourteenth, and on the nineteenth dily the worms attained nuturity and began to spin.* The spiming took from two to three disys, so that from the laying of the eggs to the completion of the coeoons takes about 30 days. It may therefore be assumed that two broods could be reared in three months, or eight in the year.

The silk raries in colour from pale greenish rellow to white. The Chinese, however, bred ont the greenisl and yellowisls varieties, and the strain now in the country is almost pure white.

\section{CHINESE MULBERRY CULTURE.}

The mulberries were introduced from Chins, heing brought here as cuttings. They are a big leaved, long iruited variety, and grow into bishes. The jungle was felled and the land was then stumped and dug over to renove roots, male into shallow ridges, and the cuttings pliuted on top of them at distances of about one foot upart along the rows, the rows being thee feet apart. The land was all carefully drained by deep ditohes and liept free of weeds by constant boeings, the plants leeing manured by the refuse leaves, etc., from the rearing of the worms. The plants beius so close, it is not fossilile to allow them to grow to any size, and thay are therefore kept down by periodical serere prunings. As iniglit be expected, hy forcing the plants to grow under these very artiticial conditions, the least neglect or disease tells rery seriously on them, particularly when they are leting continually stripped of their leaves to feed the wormis.

\section{DISEASE OF THE MUTBERRIES.}

In July of 1891 I went to Ayer fining and noticed tha all the mulberries were aftected hy a leaf discase much rescu bling in its seneral ajpenance the well-linow coffee leaf disease On the young leaves fant yelluwish dots were to he seen, and these betame larger and nore yellow on the older leaves, anel peachel a diameter of abont one-third of an inch. Benenth. these spots were more or less covered with bright yellow sporcs. 'The leaves dropped long before, in the matural course of erents, they would lave done, and the bushes looked very bare and miserable in consequence. Almost the eutire planfation was affected, but the Chimese said that the worms wotld eat the distased leat, and I saw it being given to them, and they

* In Nowember nnd December the worus clango thejr skin once more than hero stated, and ure about fro days longer in utaining maturity. 
appeared to eat it the same as if it had been good leaf. The Chimese said that the worms were quite bealthy and that deaths amongst them were rery raw. but subsequent events showed that this information was incorroct. 'I'ley admitted that in conserguenee of the disease they had been short of leaf, anl had not beeu able to rear as mun worns as they expected.

A microsonpical exanination of sections of the leaf shower that the disense was caused by a fuugus growing contirely witliin its substance. A spore evidently settles on the mander-sile of It leaf, throws out a thread which penetrates inte the first stomita it comes to. and then, finding nourisliment, increases within the tissues of the leaf, which becomes yellow and considerably swollen at the centre of the spot. One or more of the stomata on this swelling hecome much enlarged intermally, and flled with bright yellow spores, which eventially are forcel by these bemeatl them ont of the now expanded extermal orifice of the stomato.

The spores ate rather inrmular in form, some being splericul aud others oval. Tluy measure about $-\frac{8}{10,6 x}$ iuch in diameter. In water" the transpartent spore case lyecomes distended itud separated from the granular yellow nucleus, which it then encloses, as the white of an egg does the yolk. When placed in a drop of water on a cover-glass, inverted over an open vasilined well of a microscope slide. su that evaporation is prevented, the spores may be seen to swell as above stated and eventually to burst; the yellow wontents thon flout out as soparate granules. which each begin to swell mintil thy attain nearly the size of the original compound spore, uud in about four hours the swollen granules, which are spherical and are the true spores, begin to throw out slender, distuntly jounted, waved threads, somotinus hranched. Occasionally one or two of the yellow granules swe]l within a mother cell and germinate, and the nycelial thread of threads pierce the wall of the mother well, which then has the appearance of being an actual spore; but I believe I am right in saying that it is not so in reality. I lave not been able to continuously wateh for hours a particular cell under the microscope. as slould be lono in investigations of this sort, but lare only heen able to derote spare ninutes at odd times to the work. therefore it is just possible that I have misinterproted the method of germination. It is nearly eartain that the spores only germimate when in a drop of water, and attack the leaf ouly, when that drop happens to be on the amler-side of at leat.

'The nulberry which las been flinted at Ayer Funing was introduced from China. The Clivese, howerer, say that they have no recollection of having seen the leaf disorse on tho 
mulberric in China, but perhaps the climate leve may be particularly suited to the development of the fungus, while in China it is not, and the disease there may be sporadic, and do little of no daminge. Mulberries vere isitroduced into Perak from India at loast eleven years ago, and I lave examined a number of these trees and hitve not seen a single spot of disease on any of them. This shows that the disease is not indigenous to Perak, hut that it was brought aloug with the cutfings from China, and I raised the question whether the two small plantations which had been started at Ayer $K$ wning, and which were buth badly affected by the disease, should not be destroyed before it spread further, or at loast measures taken to tisinfect then.

Another question which suggested itself was, whether the imulberries which were introdued from Indin, and which are apparently both of different rarieties to that recently introduced from China, are susceptible in the same degree to the ruviges of the distase. 'To test this I gave young plante of buth kinds of those Indian mulherries to the Chimese, and afterwards also to Mr. Light, roqueatiug that they might be planted amongst the affeeted hushes. Sune two months afferwards I exinined these phans and found that they had contricted the disesse equally with the Chinese mulberits amongst which they were planted, thus proving that they wite not proof against the disease and that bat the disease ben indigenous to the country they would have cauglit it during the eleven years they have been here.

\section{INSECTS DHSTRUCTIVE TO THE MULBERRY.}

So far, I have only noticod one insect which does any considerable anount of danage to the mulberry bushes. I'lis is the conmon yellow and green diamond beetle. It damages them when in the imago state, by eating the leaves. At certain times of the yoar they are fery abundant and do serions injury to orange, lime, lewon and pomeloe trees.

\section{RAMI AS A FOOD PLANT.}

A paragraph having gone the rounds of the newspapers to the effect that it had bees fomm that romi (Chuna grass-cloth plant) had been successfully used as a food for sillworms, and that they not only throwe on it but that the yield of silk was largely increased, I tried the experiment, anil fonud that not only the worms that lad been fed on mullorry, hut also the newly hatched ones, which had not previously been fed at all, alsolutely refused to eat it, preferriug duath by starvation. I tried eut and also crished leaves with the sime result. There would therefore appear to be no doubt that rami cannot be used 
as a food plant for the varjety of worms now in Perak, though the annual varieties may possibly be induced to eat it.*

\section{ENEMIES OF THE WORMS.}

I have noticed two species of spiders, the common redilish coloured house ant, and a wasj as offenders; the most destructive being the ants, who on one occasion lilled a tray of over fifty worms in an hour or two. None of the worms seemed to lave been caten, merely stuug to death. Putting the tray stauds in cups of water and enclosing the whole in netting would of course prevent loss from these insect pests.

The house fward. rats, and the magie-robin lave also to be guarded against, as they will all devour the caterpillars whenever they get the chance, and they are most persistent in their attempts.

\section{DISEASE OF THE WORMS.}

I was informed in Augtrst, 1891, that there had been considerable losses amongst the worms at Ayer Kuning. aud on visiting the original Chinese cultivators I found that the whole of their worms had died out, and they had not a single live one left on the plices. Mr. Light stated that after atianing a size of about thres-ryuarters of an inch in length the worms went of their feed and ceased growing, and that it was the opinion of the Chinese that the worms were diseased. I at first thought that the leaf disense might be the cause of the unhenlthiness of the worms, as I failed by it microscopical examination of some of the young worms to detect any of the backeria which cause the known silk-worm diseases. About ten days afterwards I again visited Ayer Kuming, aud took some thirty of tle weak worns, which lat dropped off the cocooning frimes, and which were

* "A discovery has been made by a lady in Columbin, S.C. that may lare a marked effeet upon two preat industriog. Fur a atumer of sensons this lady has smosed Jerself by feeding silkworms and sending a few monds of weonng to the Women's Society for the Fincourarement of the Silk Industry in Philadelphin. The extraordiuary warmth of this winter caued the egirs to hatch far in adrance of the sensol, and as the young leaves of the mulberry and the Osage orakge had not pub forth, our awateur was at a loss what to do. An account adis :-

"Seeing tint the folinge of the ramie in a neithluoring field was putting out, she gatlered some and put the worms upno it. They foch ravenously, and she kept up the sapply until the Orage crumge leaves appeared. Then she divided her wormg expully, foeding one get with ranie, the other with Osage orange. She kept the coconts soprate ansi gent them to Philatelplis. The experts there were astonisligl at the sizo of those apun hy tho manio eaters, nud wrote to the lauly to know what gho hand done to secare then. They were not only larger, but the silk was firer." - Few Bulletin, No. 4 of 1590, pager 17.45 . 
unable to spin properly, for examination, as these feeble indiviluak are sure to slow distese, if present at all in abrool. AIt those that I examined nnder the microseopo were swarming with puhistophytom ovatum, of Lehert. the bacterimm which causes frolurine, the worst disense to which silkworms are liable, as it is not only infections but hereditary. Tlis distase could have no sort of conzection with the mulluerry leaf ilsease, but must lave ben imported from China, either in the eggs or ly means of infected trays or coconing frames, which were all brouglit. frotn China, or it may have been contracted in the way which will he mentioned herenter. Ou jovious visits that I paid to Ayer fiuning I bad been assured by the Chinest that they lat lutil no deaths amongst their worns, but finuncial rensons may account for their not giving correct information on this Imint. $^{2}$

The miero-organism cansing the disease is thus describer by Mr. E. M. Crookshank in his Practical Bacteriology:- "Panhistoplylon molum, Lebert (nosema bombycis, micrococcus ovatus.

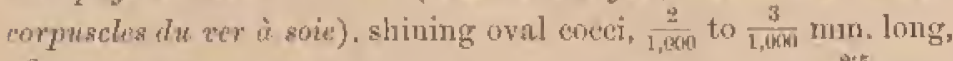

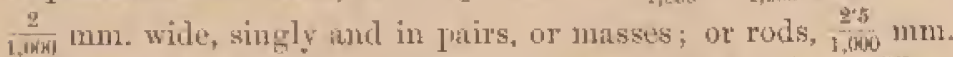
thick and twice at long. They multiply by subdivision. They were experimentally proved to be the cause of pebrine, gattine, maladie des cormuscles, of flechencht; and were discovered in the organs of disensed sillworms, as well as in the pupe, moths, and egrgs."

I hive not detected any of the three other principal silkworm diseases-grasserie, muscardine and flacidity-amougst the worns in Periak.

\section{FAITURE OF' 'HE CULTIVATORS.}

After repeated lossts entused by the death of whole broods of worns, and by the nuch reduced guality of the silk yiclded ly the silkworms, buth the original Chinese cultivators and Mr. Fight abandond the attempt of cultirating them in Felorusty of 1892, after having made a fresh importation of eggs from China at the ond of 1891. These, however, as they were matrd in the same romus aud on the same trays ats the old ones, aatumally

contracted the disense and also died ont.

\section{EXPFRIMENTAL BREEDING TO EIIMINATE THE DISEASE.}

On 10th September, 1891, I whote as follows on this subject: "Having proved the existence of pebrine nmongst the worms here, it is a suliject for the eousideration of Gowtrmment whether (a) they will take any measmes to stamp it ont, or (b) let the introduction of silk-growing in Porsk become a failure, as it most surely will without Govermment intervention. 
"The measures to be takeu are as follows:-

(c). The destruction of all the worms now in the Strate.

(d). The disinfection of the louses and apparatus used.

(e). The introduction of fresh " seed," free from disease.

(f). "The prohibition of the imprortation of other "san."

"It is probulles that the easiest way of carrying out these measures would be to get " seed" from the Government hreerling establishment in India, but that wordd entail the sending of some one to brimg it over, no the attempt alrealy mide to send it by post has fajled, for rensune previously stater].

"A second way wonld be to get " seed" from China, and rear it under Pasteur"s system.

"And a third way would he to select, by Pastemr's method, a healthy strain from the worms now in the country."

The Govermment decided to procure seed from India, but in consequence of hearing that the silk-breading experimonts underitalken in Indiu heul not proved at success, and that the oges could not be guaranted, this lad to bo ahandoned, and in November I obtained permission to try the third course indicated above.

Shortly stated, the Pasteur system, which bis sared the silk inilustry of Europe from the utter ruin wbich threntened it, is the rejection, for broeding prurposos, of the exgs of those notlis which. on examination, are foumd to be disensed.

This, in the ease of the Ayor Kuning worms, conld not be carrical out, as all the moths when they came to ha miscroscopieally examined were found to be discased. I therotoro him to tiake adrantage of a fact which las been noted by Pastenr. that althongh petrine is hereditary, still that not all the egess of it disensed mother will be infected. To cerry aut the siggestion contained in this observation, a number of sinall eluna culs were obtrined, the least diseased eggs were used, and the worms on latching out, were put four in each culs, and duritug their whole lives rigilly isolated from their fellows. The eups were frequently disinfected, and any worms wbich scuned discused removed as quickty as observed. By these means a considerable. " number of quite healthy moths were producel. The mierosenpical examination, isolation of the worres and disinfection of the house and its contents were continued, and in the tourse of three generations, the disease entirely disipgeared. This experiment has now been enriesl on for over nime months, and it goes fir to prove that, yiven a healthy lored of worns to start witl, silk culture conli lu sucessfully carried on in Perak, if proper prenations were talken to disinferet the rearing houses and apparitus, and to mintain the breed used for sued pripquses in a 
henlthy condition, by strict isolution and by subnitting it to microscopic or other selection in the maner herafter explained.

\section{PEBRINE AFEECTING WILD MOTHS IN PERAK.}

His Excellency the Governor some time back sent mo, thromgl the Actiug British Resilent, it number of the reports of the Indian Sill Committee, and in oue of these papers it was inincidentilly mentioned that petrine, the distase whioh has ben cussing such lanoe in Porak, affects other gentrat of the lepidoptern besides the crenns to which the sillswoms ledong, and it oecurred to me that an examination of the? wild moths might Ix: useful. With this object I began a microsenpical enquiry, and on the evening of the 1st. Febuary foumd a common wild moth hadly aftucted by pebrine. The kacteria were identieal in formt, size and refringence with those from the silkworms. with which they were earefully comparel, and there appears no reasomale enuse to leste to the supposition that they are not the same miero-organism, though the atetul proof-riz, inoculation-is wanting, and rather hard to apply, with any hope of obtainum positive results.

This unlooke for and disqureable discovery chearly indientes that the discase is 'ndemie in Perok, fund that, ulthough it. way be eradieated from all the sillworms in the State, or a perfectly pure breed be introdued, yet they will always be sulject to re-infeotion from coming into contact with wild pebrinons lepidotitera, or the virus ennnating from these disensed insents.

It was previously concluded that, owing to tle isoluted position ocenpied by Perak in rearard to silk culture, infection was only to be feared from outsile, and that, griven a healthy lreerl of worms and proper premstions against the introduction of disetse from Clinis or India, that the worms would enjoy complete immunity fom pehrine. This hypothesis is now apporenty shown to be falliweious, and, insteal of one eradicating the: disease, it will be necessary to pursue a contintous comses of solection of seed, if the cultivation is ever to be carried on sureesisfully.

\section{CONDTTTONS NECESSARY TO FNSURE SUCCESS.}

As the result of orer two years' observation and experiment. on the growtls of silkworms in Peruk. I lave arrived at the following conclusions.

The houses nasd to reare the werms in should be small and detached frons me another. They shomb not be too high, and be

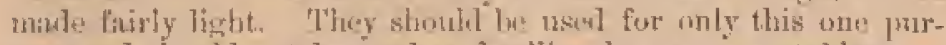
frose and shouli not be used an dwelling-housts, wor stables, nor 
as stores for heeping coeoous. They shonld be subjected to thorongh disinfection between the rearing of anch brovd, by fumigation with sulphur and washing all the trays, cococuning frames, triby-stands and baskets used to hold the leaves witls it earbolic acid soap solution. The trays used in one lonse slunded nut be moved to aunther house unless disinfectul first.

All the refnse leaves, excreta, dead worms and sweepints of the rearing houses should be removed from the houses daily, atud burned at astee, On no acount should they be used as numure for the mullerries until after lurning.

'I'le stands for the trays should be placed in the centre of the lowses so tlat they call casily be profected from insects and be got at to disinfeet, and if necessiny, realily enclosed in mettiner. Houses of fifteen teet wide would be most convenjent, with a sixfoet six-inch stand down the centre. so as to use n ilouble row of three-feet diameter trays six or seven tiers high, that is, that rach fatlion of length of tray stand would areommodatie from 24 to 28 three-fent diancter trays, giving an area of from 160 to 197 square leet. A holse 46 fert by 15 feet would therefore give 1,379 square feet of tury surfiwe. which would he suflicient for the production of from one-and-athalf to two pikuls of cocoons per brood, or say eight pikuls per year.

The stifling, sorting, storing and paking of the cocoons shonld be done as fiar as practicable from the renring houses, and all refuse from these operutions should be enrefully burned.

To be a success, a good variaty of worm should be introduced, and apparently bombyx Madrassi would be the most suitulle to the clintate and conditions of Perah. I have already remarkerd on the inferiority of the bombyx sinensis, so that it need not ln. gone over again here.

Having obtained a good breed of worms, they should be sulljected to careful treatment by the Pastemr systen to elimimate any hereditary taint that they may bave, before they are given to the cultivators. From what has alrealy been sail, it will be evident tlat it would be necessary to maintain a breeding establishment for the supply of pure ergrs. This should be some way from any other establislment, and special precautions should be taken to awoid infection from wild moths, by the use of wire notting to all windows and doors of the rearing houses. Wilh care in this respect there would only remain the rather remote chance of infection by means of the mulloery leaves used as food. having heen soiled ly some diseased wild moth or materpillar. This wo pasible merns conld be talien to prevent.

As great dillieulty bas been experienced in Indin in the attempts which bave been male, for some rears past. by the 
Silk Committee to apjly the Pastemr system to the multivoline wornts, I will state liere what my experience lats frem, the way I have carried out the system and the plan which I propose for adoption on a large scalis.

I'he motlis on coming out of the cooons are allowerl to fhir, and in the evening are separated, the mates being thrown fway and the fentales being placed each in a small conte of paper. one cormer of which is then turned in so ats to rose its lrouth. These payer cones are strung up atud the exges latit in them. On the tifth or sixth day after laying, the motlss are vach taken and erushed in little china etus with a ghass pestle. A thop of the Huid is transforred to a glass slicle ind in eoret ghas put over it. 'Illesse slides are then examined with a quarter-inch object glass and high power eye-piece, giving a mannifying power of 630 diameters. The egers of all disensed moths are then destroyed, ind the heritly ones ouly reserved for bremling. On two oecasions, starting with highly pelorinised worms. I eradicated the disease in from three to fonr generations by the above course of proesdure.

\section{PROPOSED SISTEM FOR PASTEURIZING MULTTVOITNE SILKWORMS.}

'I'he selection, by the microscope, of a limge numler of ergs. in the way above described, is it commerial impossibility, as there are only six or seven working days between the liying of the egrss whe the hatehing of multiroltine worms, insteml of alhout as miny months in the case of the anmial silliworms cultivated in Europle.

My plan for overooming this diffeulty is to mintain a breal of say 3,000 worms, which for convenience nua be culled "firsts." T'lis breed is to be liept distinct and to he mieroscon andly selectted every brockl. Our mieroseopist could examine all the fomble suoths of each broud of this number of worms, thetween the lay. jun and latathing of the eggs. A certain number of the corps from the best eocouns wonfil be fout aside fur the next generation of

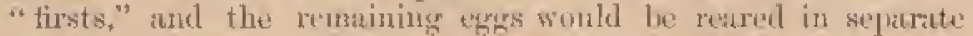
bouses, in which strict sanitary precuntions would be maintained.

This hood, which would not be microseopically selected, maty le malled "seconds." On attatning maturity these "se'eonds" would lay, and it is their eggs which would be given to the enltivators.

H'loy would therefore be always only once removed from the "first" or microscopically selected cgos. If 1,200 temale moths out of the 3,000 above-mentioned were passed at a 
schertion of "firsts," they would yield, say, 240,000 erress, or 120,000 female " scomls," which again would yiekt t-4 millions of egus for distribution. "This number of worms would give 16.458 tons of "green" coeoons, or at four bronds ber anum, say 64 tons, as the outcome of the work of a single microsenpist. for a year. 'This is as moch ats a hundred microsecopists could dis, with multivoltime worms, if working by the ordinary method of selection as practised in Europe.

The whole system ilepents on gutnoliny from external susurces of contagion the gentration after that which has becs proved to be tree from distase by microscopical exmmination. 'Th de this, etenuliness, the free use of antisepties, isolation, and Jie growing of the fool in a place where it will not be infected ly unhalthy worns, are the main points to be attended to. $A$ s "t precultioniary measure, the "firsts" might be divided atrantubeulsly, and lent in two seprarate houses.

Fron time to time it minht be necessary to introduce fresh blood into the lreed. and for this purpose the fresh worms should be microswopically selected for four or five generations before mixing them with the original "firsts," heing lent during their probation in a homse isolated from all the others. It may be mentioned here that I have foumd that a single selection, never unind how carefully it is done, is insutticient to uhininate pebrine from a race of worms. Theretore it follows that it is viseless to attempt to produce " secouds " until the "firsts" have been thoroughly purged of all traces of disease, by repeated selections.

In an establishment such as is here suggested, the microscopist would be the only highly paid man. All the other work enuld be done, after a little tinie, by ordinary wolies, so that the cost of maintenance would be conparatively unimportant, and the eggs could be supplied at a luw price.

I venture to think that this system, if carred ont properly, will do for the multiwoltine sillsworms of the tropies what the system practised in Europe has dome for the anumal silliworms of tempurate climates.

\section{SET.ECIION BY LONGEVITY.}

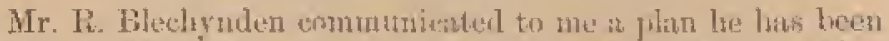
trying, to effect the solection of hetalihy worms for lnectiug

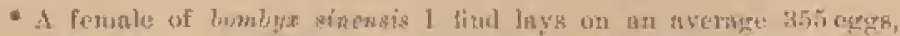

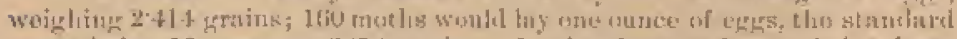
ounce heing 1 is arams or 380 s grains. In the ubove estimates it has been. aEsumod that eate moth will produee only 2001 wos ms. 
[mrposes, without the use of the mieroscope. The system consists of the placing of each fenale moth under a small cup inverted on a sheet of paper, on which it lays its eggs. The cups are suffered to rentiu with the eggs and moth beneath them thatil the eggs lowin to hatch, and the expss of all those motlis which are alive at that time ore taken to be healthy, and those which have died prior to the hatching of the eggs are thrown away as unhealthy. I have experimented with this system, and there appears to be a good deal to be said in favour of it; the moths which survire being almost without exception healthy; though it by no means follows that all that die carly are diseused. 'I'o deal with the same number of moths as montioned ahove wonld, lowerer, involve the manipulation of athont 150,000 clinat crps, and would requare over 4,000 square teet of table stuffuce te put them out on. It has the great disidvantage that the eggs cumnot he distributed as eggs, ind that the young worms could only be sent in short distance from the breeding establishment. In the system adrocated above, either the coeoons of the "geconds." or their eggs could be distributed, and there would be plenty of time to send them long distances.

\section{CULTIVATION OF MUTBERRIES.}

From the experience aequired in Larnt it would appear that the best way to cultivate mulburies would be to fell the jungle, burn and olear it as if going to plant pali or cotfee. 'Phen put in the mulbery cuttings, or better, the youmg plants, previously ruised in is nursery, at distanees of 12 feet by 12 feet, that is. 302 jlants per acre. If it is wanted to beyin picling early, they might be plauted at of feet by 6 leet, of 1,210 per ikreand every other row, and the intermediate bushes of the remaining rows, being picked at first, the bushes which bad been picked when young being afterwards cut out, as the mpicked ones grow larger and require more room. It these latter are allowed to gTow to 6 feet in height and to boome larpe spreading bushes, they will last for years; lat when grown as the Climese grow then. which is an attempt to violate all the conditions which the plant nitural]y requires to be fulfilled, they are very dulicate and susceptible to the influenee of orer-piching. disease or neglect of weeding, and are very apt to die out. 'They should never bo fricked too close, as it is always to be remembered that the leares are the organs which supply a plant with its principal lood, that is, the whole of its carbon, and indirectly with all its other food, as without the leaves to exhale the watery portion of the sap, the roots camot alsorb moisture from the soil, and unless they absorl water tbey eamnot acquire nourishment from the soil, as the water is the medium in which the nutritive parts of the earth ure conveyed to the plant through the roots. 
'The busl varieties of mulberry have hitherto been ouly cousidered, but it appears that the tree varieties are in some situtations to be preferred, or at least, night he advontageously planted in conjunction with the bish virieties. They noed not be weeder after attaining some size, which to a Malay is a great consider. ation. They ean be planted amongst other tress, and as lredges to fields, kimpongs, etc. 'The worms appear to eat the leaves, and thrive on them. I have found no difference in this respect between the two varieties, except that the busls mulberry is nore snited to the woms when very young, as the leaves are much softer.

The multwries can readily be propagated lyy cuttings. These are best mado when the plant is at rest, thongh they mas, with care, be got to strike at any time of the year. Pieces about a span loug are the best, and they should be cut at the bottom end, close beneatlo a joint, otherwise they are very atj to damp off. They grow best when phanted upright, and with not more than thee inches of the entting benenth the surfuce of the grouml. If trented as the Chineke and Javasese usually treat cuttings, that is, planting them diagoually with three-quarters of the whole length of the slips beneatl the groumd, not one in te'n will strike; whereas if planted rs recommended, not one in ten will fail.

Apparently, fon or fire broods of silliworns corald be raised in the gear. 'The mulherry appears to have two growing seasons during each rear in Penk, but sufficient experience has not yet betn necuired to enahle it to be definitely stated when it would be best to ren the broods.

The refuse from the ronring honses should all be burned before it is returned to the land as mitnure, as it would appetr by the expretence gained in India that the disense gerins eontained in this refise gret on to the latves and infert worms fed on them. This enu be easily umberstood when it is remembered that the germs retain their vitality for a period of at least eiglit montls.

\section{LABOUR.}

The main condition that must he fulfilled to ensure the successful brewling of silkwoms in Perik, or anywlere clse for that matter, is employment of cheap labour. 'The mining in this State has raised the wages of all classes, particularly amongst the Chinese, and though $\bar{T}$ bave not bens able to collect any reliable information on the subject. I do not think that silk could be produced by mentis of Chinese labour at a price that would be remunerative. If it is to be successfully grown, I believe it wotd be by the Malays, as amongst them the wages are lower, and women and children could he employed for all the lirht portions of the industry; which they can do not only chuper, 
but actually better than men. The Fuala Kangsar and Krian Cistriots ave the most suitalye, as in both pliwes there is an conparntirely thiek Malay population, and rery little mining near to raise the price of labour. If some Malay chief of weight could be induced to exert his influence on the people, silk culture might. I teliove, easily lwe established amongst the Mithys. It is essentially a peasunt industry. To enry out this suggestion it would be necussary to form nurseries of mulberries in the district choseu for the experiment, so as to be able to supply plants to the Malays, who should he induced to plant them in their knmjongs-not only those whe are intendins to rear the worms, hut others, who conld afterwarts sell leaf to the actual keepers of the worms. On no aceount should the Arer Kiming mulberries be used to propugate from, as the letf disense would be propagated at the sime time.

Having secured the planting of the mulherries, the next step would be to show, by an actual demonstration in the district, the way in which the culture is to be carried on.

Pure egrs would, of eourse. lave to be supplied, but by the system alrualy explainet in detail, lialf in day's work with the nicroseope at each brool would be sullicient to supply ull the eggs neoded for a long tinze to come.

The sill when proluced should either he reeled locally by the enltivators, or the cocoons should be sent to Furope for sale. If roeled lotally it must le dous well, or the price is seriously reduced. Reding is almost always done by womell. and lere agrain the only people who would hes suted to the work would he the Malays.

\section{TAIPTA,}

September 21,t, 1892. 


\section{FXPLANTON OF PLATE,}

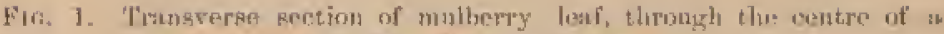
rlismase sput. Magnilien 51 ditumetors.

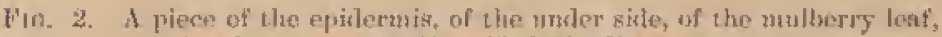

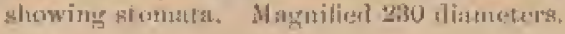

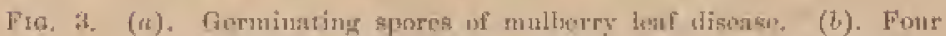

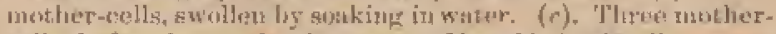

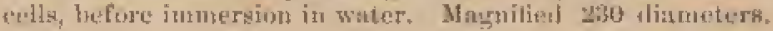




\section{ON THE MALAXAN FISH POISON CALLED}

\section{"AKER TUBA," (I)TERIS ELLIPTTOA.)*}

The fish-poison known by the Malavan name of " ther tuba"

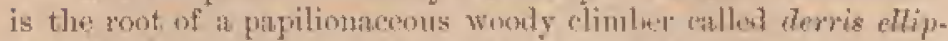
lime, Bentli. This plant bears bunthes of protis, frugrant, white flowers, tintes with pink and pale buft, which are followed by thin, flat. blunt-anded pokls, $2 \frac{1}{4}$ ineles long by 1 inch boat, containing one or two sweds. The leaves are pinnate, with sereu to thirteen leaflets, atud are whitish benuth. It flowers in Perak in February and Mard, and the fruit ripens in Miy or June.

'The following is the botanical deseription take from the Forest Flom of British Purma, ly S. Kul\%:-

"Derris Ellipice, Bentl,-A large samdent shmb, the younger parts all rusty pubesent; leatlets, in fom to five pairs. with an odd one, on ia puhesent petiolule 2 lin. lomg, oblonis to obovate. lanceolate's shortly and rather ahruptly acmminate, 3 to 6

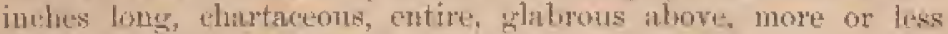
glatrescent beneath; flowers rather large, pinkish, on 2 to 8 lin. long, rusty vilkns at apex, brateoled pedicels. preduncled-cymulose and formmg in elongitte, rusty, puhescent, narrow pan icle in the axils of the leaves or atuve the scars of the fallen ones; corolla inch long, appressed, tawny silk-hairy ; ovary, tawny villons; pods elliptic, compressed, mather acnte, ahout 2 inches Iong by 1 incl brust, 1 to 2 soeded, pulwertous and glabrescent, narrowly winged along the vexillar suturo. Habitat, Ieunsserim. Flowers. Mitreh ; fruits, August."

Lourciro's guans Derris includes several other poisonous plants, of which $D$ ). Uliginos a, Benth.. and $D$. Forsteniana, B1., are also used as fish poisous in Malaya. Otler nearly allied generz of the papilionaceous leguminose contain species employed for the sarue purpose, of which Pongamin, Miltutio and Tephrosia mizy le mentioned.

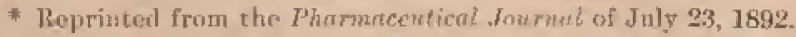

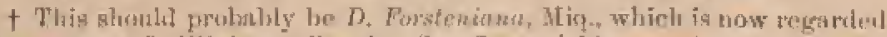

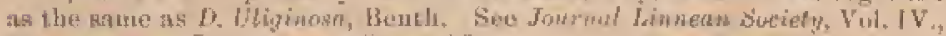
Simplement. [Fo, Phurm, Iosimal.] 
Aker tuba grows apjarenty wild on the plains in Perak, and is nlso rather extensively cultivated. 'The roots, done up into bumdles, are to be bonglit in many of the shops, and in 'Thiping, the chief town of Perak, it sells for about 35 cents per liati, or $9 \frac{1}{2} d$. per pound.

The root, which is the most virulent past of the plant, axules, when cut, a white milky sap, which under the microscope is saent to be an emulsion. The roots have a mather pleasant aromatic resinous sucll, bearing a slight resemblance to that of liquorice root.

It is used largely by the Chinese morket gardeners as at insecticide, for which purpose the fresh roots are clopped up fine and then pounded and mixed with water, which becomes milky, and which is sprayed or brushed over the plants with a bunch of fenthers.

The main use of the plant was, however. until the much. needed prohibition eame into bores, the a fish-poison, for which purpose it is pounded or ground fine and mixed with stiff clay and crushed refuse shrimps or small fish, and the mixture is then make into bulls and dried. These halls are thrown into the sen, like ground bait, and fish eating them beeme poisoned, rise to the surface, and are canght by the watohing fishermen. 'I']is way of using it is probably not rery harmful, though the samn camot los stid of its use in Eresh waters.

By the Malays it is nochl in the rives in the following way:One or more dngent canses, according to the size of the stream to be ozerated on, are partly fillerl with water and the poumder. roots. 'The man then upset the loot or boats into the river, and allow the other boats to drift down with the current, whilst with nets and spentrs they secure the fish as the rise stupefied to the surface. It is a most destructive methor of fishing, killing as it does all the fisb, little and big, fol sone miles along a waterway. The roung fish sucumb much more radily to the poison thin the larger ones. In pmils and pools the destruction of the fish is even more complete thu in a river, and the Malnss say it is years before they beome temanted witl fish again. In all iustances, besides the actual effects of the poison, the fouling of the water by the decomposition of the lodies of the fish and animals of all sorts has to be taken into consideration.

By experiment I baxe found that 20 grains of the green ront will render one gallon of water suflieiently poisonous to kill fisl.

* Figly poisoning is still, however, enrried on. In March of the preseut year (1.693) I saw a large party tislinge in ome of the rivers; fully bout jeople were engaged, nod may bont-lonks of liph were cuaglit and now.

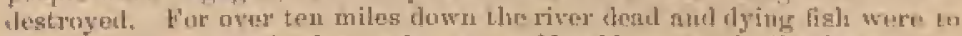
bo seen. Dymantite is nlso used to a consiclomble exteut in the State. 
The: first offects of the jwison on it fish ane to canse it to make viulent afforts to escalpe, jumping ont of the water, mpidly swin. mines alvout, ete. 'Then the brathing becomes lizboured and there is it slugrishess and uncertainty of movement; thex next symp. tou is itn increasing instulity to mantain the ordinary position; then the fish turns on its back, rises to the sturfiter, and the hreatliing becomes slower ant finally arases. When fish have reached the state of tuming on their labeks and rising tos the surfiace, they will, if put into fresh water. slowly revive, and atter the lapse of seme hours ippear little, if any, the worse for the experiment. I lave thate times prisoner it fish, allowing intervils for it to revive; and it less lived in an uquarium for days or even weeks interwards.

'T'le' poisoluots primejple is not, ats might be expecterl, atn alkaloid. I at first tried the usual metheds for sepotating these substances, but the residues from the exhanstion of both acid and allkaline aquens solutions by etlee and chloroform did not posstss toxite effects. After many experiments I found that the fwisonoms prineiple, for whish I jropose the name " tubain," is is rery lnittle, redilish-hrown coloned, resinous substance, quite iusoluble in water. puraftin oil. and benzius. but soluble in aleolobl, et leer and chloroforn. It has a specific gravity of $1 \cdot 160 \% 2$ is disBolved hy nitric acid, furming a loright dragun's-blood red solution; and is mancted on by strung hoiling solution of carbonite off sorlis. Whetrz heaterd in a glass tubes it melts, boils, and then corlonizs, ix brown-colestred oil condensing of the cool part of the tube. It burns with a large snoks flame, leaving a quantity of enbonacous ash. Fractional distillation and other mens

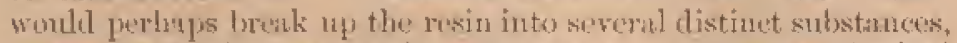

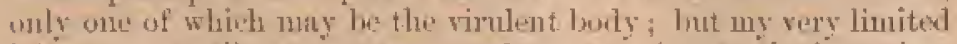
lathowiory appliances provent me from carryitug on the insestightion further than I lave done; and I must leave to others the fiuther working out of the suliject.

'lubin is most eomveniently mepared ly crnstring up the whopped rowt and diresting it. Witl little leest, for some homes in alcohol acidulated with livdrochloric ateid, filtering and evaluitioting on a water-bath at a low ternperature tuntil is pumny substance separates. Whes atl the spirit has evaporated and water

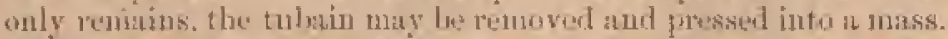
'Ilis oun then lo: washed ly kneading in lot. water and further

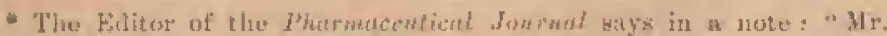

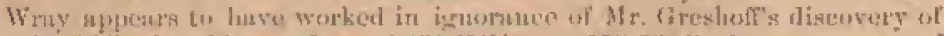

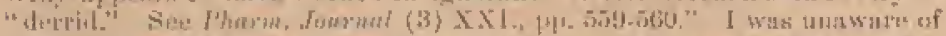

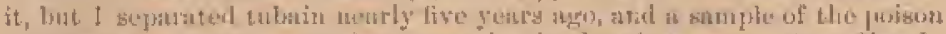

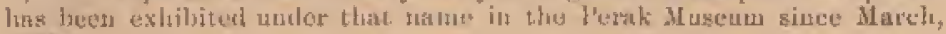
1558 . 
purified by re-sulution in aleolol and repeting the above process. The result will be the resinous substance above duseribed. 'The routs slould be digested a secoul time in fresh alcohul. The dried rust yields ? 42 per cent of tubain by the alowe process. Whe tubain is dissolved in spirits of wine and left to stand, th grantar de'posit of a dirty-white: colour is formed, wlich is only sparingly soluble in cold aleohol, but is dissolved by hot aleohol, chlorotorm, amul ether. 'I'his sraulatr body redeposits oll evaporation from wher is in pure white crystalline talsteless muss. From its solution in chloroform it is left as a clear white varnish. When luater it melts into a transparent white thid, which on an in(ereast? of heat turns luownish-red and partly distils, nualtered. I'his substanee when freed from all traces of inbuin (by repeated rerystallization from hot alcoliol) is not prisonous to fisli. IThe acid agueons solution left after the deprsition of the tubain, and whioh contaiss prestumably any alkaloids present in the routs, is also nut poisonous.

One part of tubin in 350.000 parts of water moves quickly futal to fish, and water containing the extrordinarily snat] quantity of one rullionth-i.e., 1 grain in 143 fromels of water, will hill tish in from ons-gurter to half an hour. aceoriling to species. 'There is a considenale difference in the susceptilility of various kinds of fish to the effects of the froison, ind the sihride, or cat-tisles, appear to be the most tolerint of any. It has been strated that fish killed by aker tuba are sumetimes unwholesono, fut when we see the extremely sminall amount of poison which is required to produce a futasl result, it serems improbable that any ill eflects can le produced by enting tish so lilled; the note sô as tubain distils over with the stenun from boilius water, and would be, in part at least, elininated

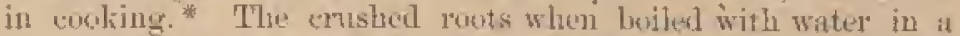

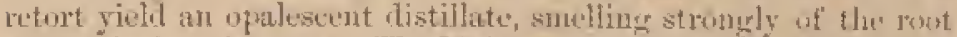

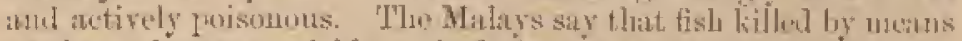

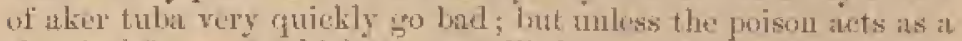
clemient ferment, which seems unlikety (as tubitu adeled te milk catuses no clange, and, if anythine. mather retarts its turning sons) it is more probable that the haterises lrom compariug tist caught alive and remainting so in the bettum of a loot for some hours

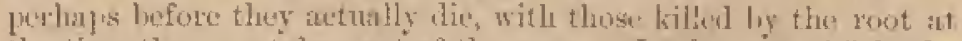
the time they are taken ont of the water. In the case of fish. the poison is evidently alssorbed ly tho trills, and passes at onevo into the eirenlation of the blemel, which prolsally aceonnts for the infinitesimal doses which are enongh to produce lethal restlts; for

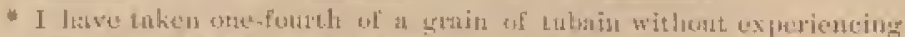

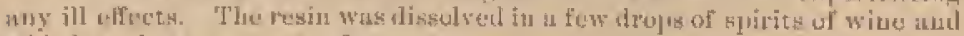
added to about at onuce of water. 
with most poisous this is by far the most effective way of ackministering then. Owing to the insolubility of tubain, it naty be eaten ly a tish with impunity. I have seen in fish cat enougli to kill a score, without any ill effects but when a solution of it in spirits of wine is added to water, althomgh the tubajn is at once precipifated as a b]uish-wbite cloud, still it is then active. Presunaluly, the fine state of subdivision enables it to be assimilated by the animal organism. In the sup of the plant it exists as an cmulsion; and the sap, hizving nus tendeney to contulate, may lx diluted to any utent witls water. By this means it becones an extrensely atfenuated enulsion. When the roots have become dry. this only tales place to a very limited extent; and a solvent. is then necessary to bring the tibain intora form in which its poisonons qualities an be alplied.

There appars to be no reason why we should not take the lint from the Chinese malrket pardeness and aply the poison to the destrotion of the many insect pests to which garden aud freen-liouse plants are subject.

From what has texen said as to the nature of the substanee it wil] be apparent that the dried roots would be of little or no good for the purpose, and either the tulyais mast, after being extrasted from the root. We converted inte an emulsion or intes some clemical combunation easily dissolved in wator. By the aid of a small quintity of spirit it maty easily le enulsiticd with soat?, which on solution in watur presents the poison in an active form. I think it mey also be saponifien if mixed with oil lefore it is treated with alkali. My attempts in this direction heve been only partially successful as yet. In both cases jottish, or soft soays, Would be the most conventut rehicles with which to emmbine it, is they are so much more readily miscible in water than the sochit soups. The extraction of the poison fron the roots in a large waty would wot be costly, as ly suituble apparatus the spirit condl

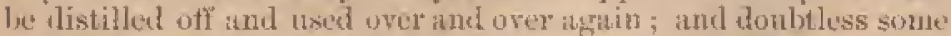
eheaper method of extricetion could be found. 'llhe plant grows readily in the Straits Settements. The roots are ding up from time to time and the stumps and suckers are replanted and soon throw ont new roots. The stems also contain the poison, though in not so great a proportion, but still worth extraction. It is probable that the best time of yent to harvest the root would be Jamury, as the plant is then at rest and nearly leafless. This is it subject which seens to be well worth the attention of the makers of insecticiles and of Horiculturists and horticulturists generally. *

Taipina, 12hh Mareh, 1892.

* Sev also Keto fiardens Report, 1877, 1. $₫ 3$, and Pharm. Joternal (3), XYII, P. B. 


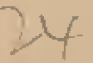

\section{NOTE ON A LIGHTNING DISCHARGE IN TAIPING.}

During a thuuder-stom on the afternoon of Sundiay, the 5th Mard, 1893, two trees in the garden of Colonel Walker. at Tuiping, were struck by lightning. The ense is worthy of record, as there were several points of considerable inferest connected with it, 'The trees which were struch are hot holut the Malays call "pulati" (alstonia ncholaris). They are not largou ones, and there atro several considerably faller close by. T'hey are situated in a small frollow surroumded on three sides by high ground, the slopes of wheh are dotted over with trees, whilo an the top of the rising ground are three luildings furnisjed with lightuing couductors. The bnildings are Colonel Wallitr's louse, the manazine on the fort, and the Secretary to Government's quarters. The two pulai trees are therefore jn, no way conspicuous objects, and it is hard to understand why they should lare been struck when the visible nspects of the situation are alone tation into aceount; lut the state of the almospliere may have been such that a path of lower ulectrieal resistance was opened to the discharge through these trees than throtgh the higher ones close liy.

Temnysou aptly describes this coudition in the lines-

" "llie ragged rins of thunder brooding low,

With shadow-streaks of rain."

These shadow-streaks, which are such a noticenble feature of tropieal rain-storms, offer an casy explanation of the otherwise inaceonutable occasional selection by lightning of innonspicuous objeets. They often sover, witl their bisses, quite it sunall area of ground, and their deusity is such that they must offer very much less resistunce to the passage of an electrie current than the surrounding air.

The trees themselves were not iujured, except that tho top shoot of one was broken and that some twigs and leaves were 
eut off and scattered about. 'T'le bark was neither stripped off nor were there any nusts on it, and, beyoud the slight damage 16 some of the leaves and twigs already mentioned, there was miling to show that a powerfil diseliarge had traversed them. On the ground surroming the trees, lowever, were evidences of an unusial churacter. Aroumet and hestween the bises of the trunks the ourth was torn up to a depth of a foot or more, and

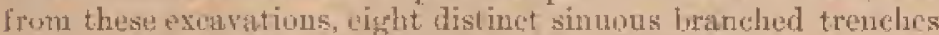
were cut in the ground. The two longest of these were some fifty-eight and fifty-four feet, the latter of which terminated in unew of water. "Two of the ather truches also terminated in water: the others diminisher in size as they extended from the trees and gradually dien out. "Near the bases of the trees the furrows were from nine to twelse inches deep and ahout a fowt wide. The roots in the earth were all cut througl, and the earth, fieces of root and turl bal evidently heen thrown out with great foree and seattered all orer the place.

It is quite likely that the damage to the leaves and twigs of ilu: trees may have been caused by this ajected earth. for in a (atse in which a buikling in Thiping was struck some vears back. part of the discharge passed hetween the lricks and the ylaster of the wall of one roon ant the plaster was thrown with such force that it did a large amount of damage to the contents of the room, which was then used as the Museum. The velocity of some of the particles of plaster was so great that they pierced Glass bottles at it distance of twenty foet, making denn-etut holes in thom. In that mse it may be mentioned that the particles of plaster were thrown at right angles to the line of ischarge, and if the saue thing hapryened in the prosent instance the earth would hitye been projocted vertically upwards.

In places, tmmels were cut in the earth for a length, in sone atases, of eight or ten feet. At the three points where the disclarge loft the earth and entred the water, the curth was ejected is if the direction of the infoelling force was from the trees towards the water, in other words ats if the flasls cane from the atoud to the eartl. Two of the trenehes leading to the water ender in tunnels and one in an ofen furrow. Tle tunnels wero rouncl pigk-like exeations ahout three inches in dinueter, witlt their orifies on a level with the surface of the water.

The acempanying rough slivtal shows the furrows and their sinnous, lranched chatiacter; the dottod lines indiate the tumuels. As will be seen, the phlace was duarly surrounded by water, and the mere fact of the trees being julat will be sufficient to show that the! spot was low-lyine and damp-in fact, the natural water-level in the soil is only about eightern jnches fernenth the surfice. 
On looking at the sketeh it will be noticod that five of the trenches start from excavations at some distance from the bases of the trees. There were no signs of inmels connecting them with the bases of the trees, so that it wonld appoar that the lightuing must have branched before it reached the ground.

Another point shown by the sketch is that the trees nust luave been nearly, if not quite, in tlac centre of the clarged areit of groum. I'lis is indictted by the even way in which the furrows radiate from the bases of the trees. 'The area of ground covered by the furrows-that is to sir, which is enclosed by drumin a line so as to conmect their outer cxtremities, is about 3,500 square feet in extent.

There had bevn beavy rain lefore this particular fiash (which ocxurred at th few minutes to six o'clock in the evening) and the surface of the ground nust huve ben very wet. Ovir one inch of win foll duriug the thunder-storm, and certainly more than half of it fell prior to the trees being struck. The ritinfill for the week preceting was as follows:

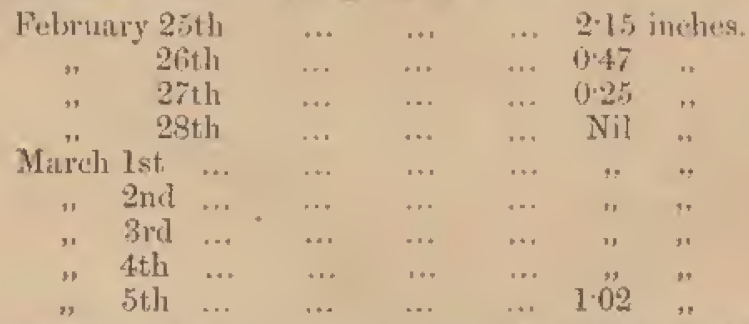

It will be seen that there were three wet days, with a total rainfall of $2+87$ inches, followed by five dry days. Before the rain commenced on the afteruon of Sunday, the 5 th Mards, the surface of tho gromen for some few inches in depth mist therefore have beew fairly dry, and at the time of the flast it is probable that there was still a layer of dryish eartl between the wet surface and the saturated subsoil. It was through this top layer of wet earth that the lightning passed, and the less moist lager beneath it seems to have proved an effective insulator.

A study of this discharge tends to enst doulit on many of the ideas respecting lightning and lightniug-conductors. It secms to show that the charge is strictly confined to the surface of the gromd, and thet the discharge under certain circumstances spreads out disruztively on the charged surface and does not penetrate into the earth, although, ats in this ase, it. would onty lave hat to go through a few inches of damp atath before reaching the water-level. Instem of this it will be seen that some of the furrows rin for a listanee of over fifty feet, just 
beneath the surface of the ground, to reach charged pieces of water, throwing ouf branches on their way to diseharge the intervening surface of the ground.

When anything similar to this takes place on or near a builing on which there is a conductor, it is at once put down to at had enth-onuection, while apparently it is due ts the wet surface of the ground being a better conductor than the stratum lying letween the subsoil and the charged surface.

Catses in which large numbers of sluep, cattle or people lave been killed by lightning are eusily comprehended, after looking at this sketeh. It is evident that hat a number of people or cattle been standiug beneath these trees and occupying the space covered by the furtows, that they would lave constituted the chatged surface and that the dischatge womld have passed through their bodies instual of as in this instance, through the ground.

The practical deductious to be drawn from this case seem to be that all surtaces which are liable to beenue charged should be jut in conmunieation with the system of conductors on in building. In other words all roofs should be connected by their ridges and gatters. While, as much as possible, lightning conductors slould be arranged so as to be lightning distrilutors. For this ptrpose all the condnetors on it builling should he connected together, and the eartloplates so spaced round it that the discharge may lo spread out over as large a surfitce as possible. 
ON THE BLACK LIMESTONE A'T' KAMUNING.

On the road lintwen Finggor (on the Perak River) and Ipoh, and at ahout nime miles from the former place, is at picturesque? limestoue hill ablled Clanghat. Fammung. It is lerthaps some fo0 to 800 feet in height, and is munposed af at black limestone differing in many respeet from that of a similar colong found in other parts of the State.

The limestone is nemrly black in colour, with oxmasional veins of pure white. It is soft and is easily eut with a linif. yichds a crey powder, and las an uneven fracture, dull in tl. tirection of the grain and minuty sparting aross the main. It blackeus the lands when haudled, and when rubbed with it hard substanee prosents a polished black sisfince. In thin sectious under the microsoope it is seen to be made up of whit: erystalline carthonate of lime, enclosing opaque black shining sciles and irregular masses. When a fragment is nut into difut. acid the lime dissolves, leaving a black powder, which nuder the microseope presents the appeatance, in miniature, of pieces of coke. The grains are of different sizes and very diverse shapes. The fowder is slightly gritty hetween the fingors, from admixture of a small amotme of quart\% sum. "Ilue particles of this sulstance, by their appearance, suggest the jeden that they have been in a plastic state and that the arystallization of the en. ulosing calcite gave them their present form. This is leest slowu in a decaleified section of the rock.

The hlawh powder when rubbed on japer, of between the fingers. presents the characteristie apjentance of plumbago, whilk. before the blow pipe it letheres in the same way as that substance, and if heated with nitre it deflagrates, It is therofore carloon in the form of graphite. 
BLACE LIMESTONE AT KAMUNING.

'The rock has a specific gravity of 266 at $84^{\circ} \mathrm{F}_{\text {., }}$ tund cousists of-

$$
\begin{array}{lllllr}
\text { Carbonate of Time } & \ldots & \ldots & \ldots & 91.4 \\
\text { Carbon (graphite) } & \ldots & \ldots & \ldots & 8.1 \\
\text { Silica } \ldots & \ldots & \ldots & \ldots & \ldots & 5 \\
& & & & & \multicolumn{1}{c}{100 \cdot 0}
\end{array}
$$

Ineluding the arbon in combination with the lime, there is nearly 20 per cent of that substance in the rock.

When dry, the stone is a fuirly soud conduetor of electrieity, and if an fiece of it and a slip of zine are applied to the tongue, the well-knowu sensation produced by the passage of a weak current of electricity will be felt.

From the oecurgence in the immectiate netimlourhoud of the upper beds of the schistose rocks which unlerlie the lime. stome formation of Perak, it would ajpar that the Kamming ineds belong to the lower part of the calcareons series. It should the stated, however, that the limestone which rusts on the mader. lying beds, as fur as has been olsserved in other parts of the Srate, is not cartwanceous. Whether this is a sign of unconformity, or is simply due to locil cutses in ojurution at the time of th. rejosition of these beds, is, w the present state of ont kuowhles: inpossible to determine.

Timestores cuntaiuing graphite have been found in Cancula and the northoris pats of the United States. These rock are of tho atrohat probert, and it is in them that the much disputed Euzing Conulente meturs.

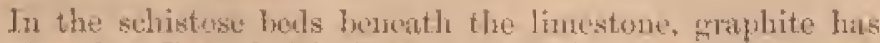

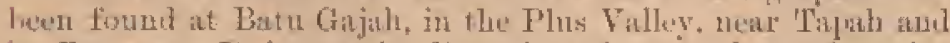
in Bernotm. It is mostly disseminated in scales and grains through the body of the rock, but at Batn Gajith there is a welldefined vein of it. This vein was ont in making the new rourl to Tahat, and more rewently again in sinking is well in the hospital grotuds.

A consideration of the chatucteristios of these schistose and

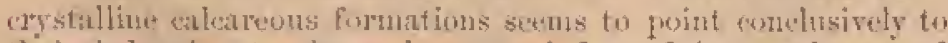
their loelonging to the arthonan period; and it may be stated that the whole of Perak, where the granitic rooks have not burst through and come ut to the surface, is coreted by leds of the Iaturentian fommation, as no rocks of less age are kiown to exist, exeept the very recent quaternary drifts and alluvial deposits. 






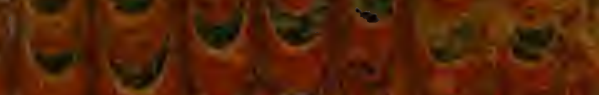

(2) 128

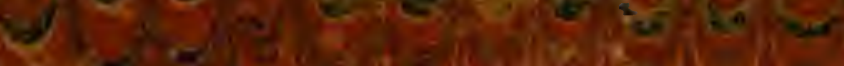

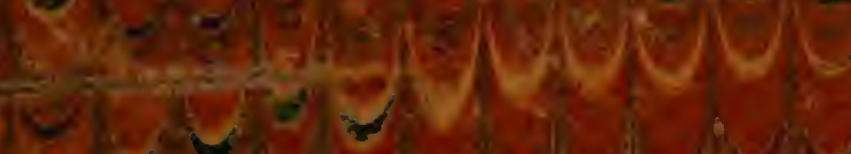

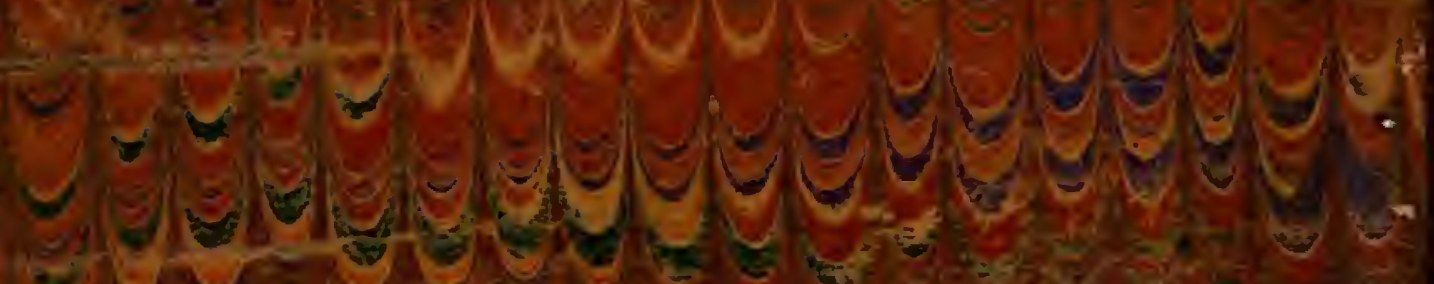

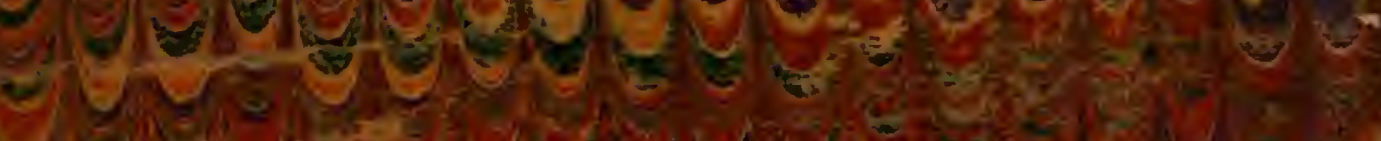
4.

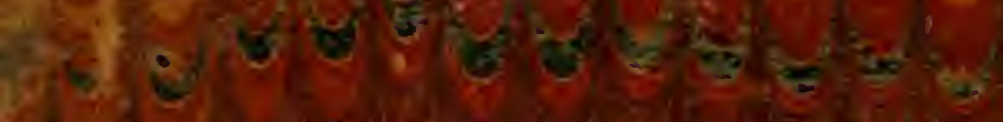

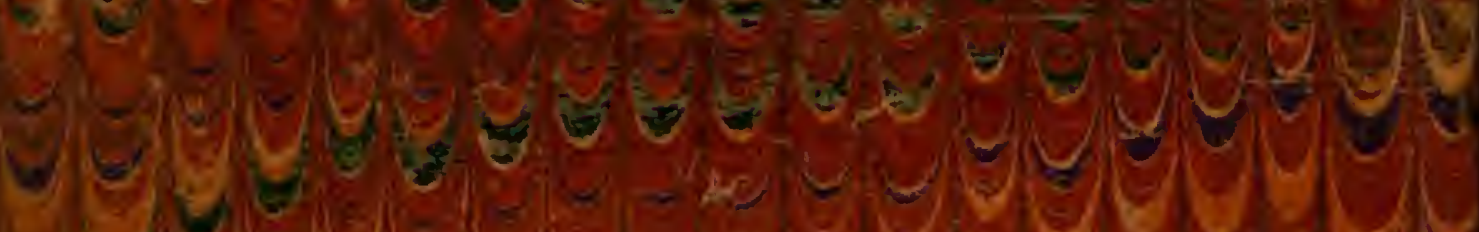

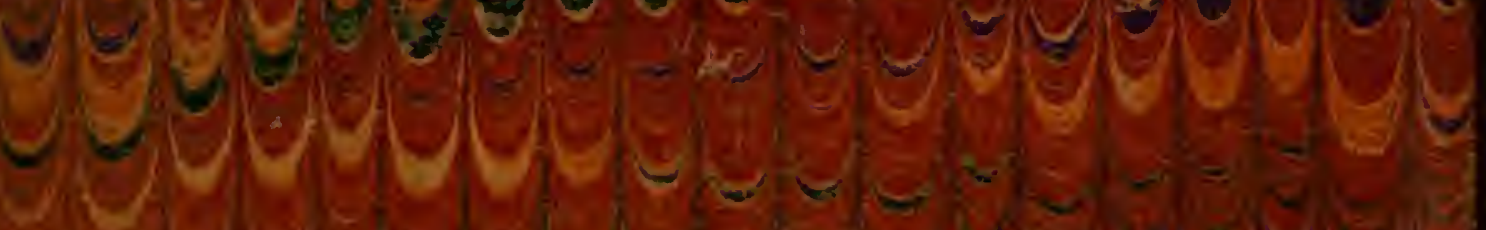

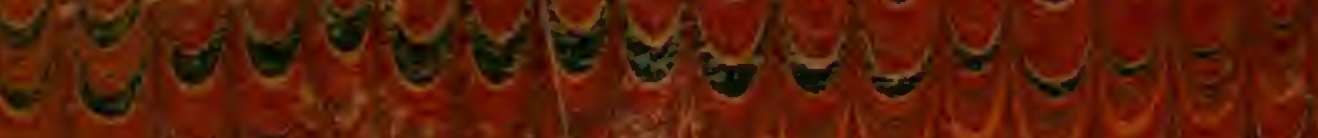

Y.

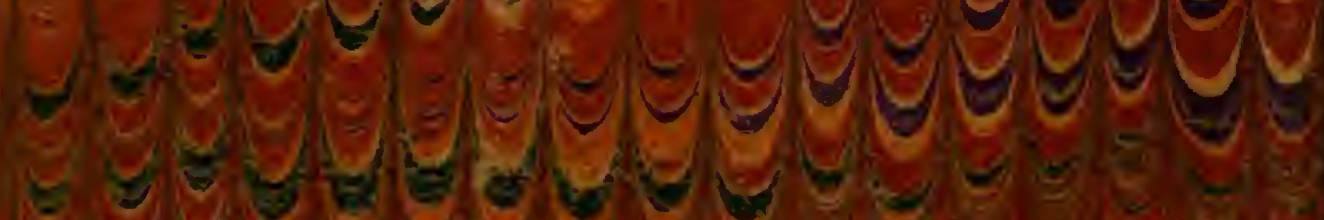

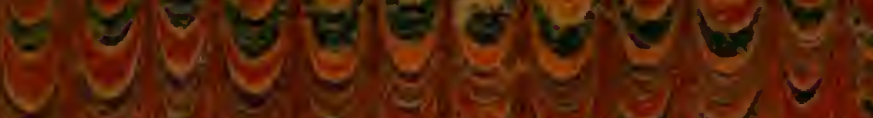

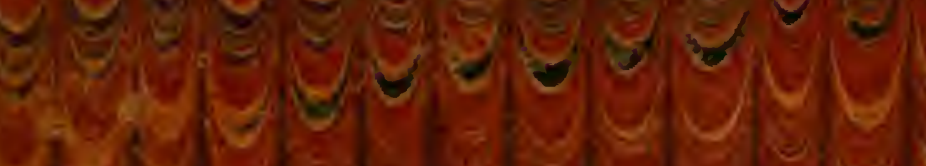

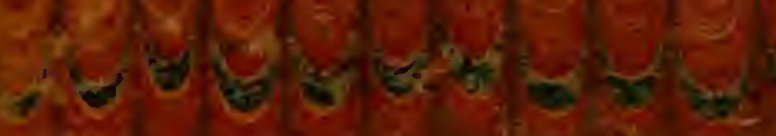

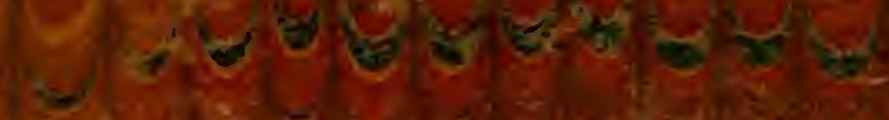

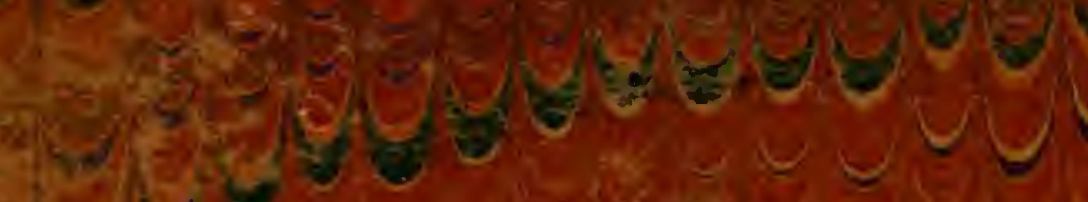

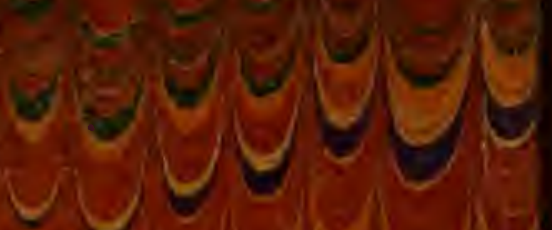
yyse

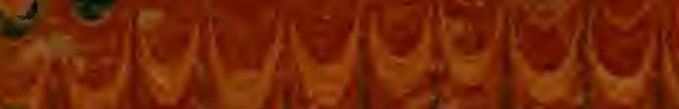

